\title{
Temporal and spatial dynamics of the invasive red king crab and native brachyuran and anomuran larvae in Norwegian waters
}

\author{
Helena Kling Michelsen*, Einar Magnus Nilssen, Torstein Pedersen, \\ Camilla Svensen
}

Department of Arctic and Marine Biology, UiT The Arctic University of Norway, 9019 Tromsø, Norway

\begin{abstract}
This study investigates the temporal and spatial patterns of larval stages of the invasive red king crab Paralithodes camtschaticus (RKC) and co-existing native brachyurans and anomurans in a Norwegian fjord. It is one of few field studies describing the larval stage of native and invasive brachyurans and anomurans in the southern Barents Sea. Larvae were collected at 6 to 18 stations at roughly 1 to 2 mo intervals over a 1.5 -yr period. To help explain timing in hatch of RKC larvae, the reproductive state of females was determined. The first larval stage of RKC was found in higher abundances in shallow bays, reflecting the spawning migrations of reproducing females. RKC was the first species among anomurans and brachyurans to release their larvae in Norwegian waters, and due to an extended larval release (January-May) their larvae occurred for the longest period of time in the water column. The native boreo-Arctic Pagurus pubescens and Hyas araneus released their larvae early in the year, starting in March. In contrast, larvae of the native boreal Pagurus bernhardus, Hyas coarctatus and Munida sp. were observed later in spring and summer. The combination of protracted hatching, high fecundity and high adult abundance of RKC are likely strong contributing factors to the species' successful establishment in the southern Barents Sea and could favour the dispersal of RKC south along the Norwegian coast and potentially north into Arctic shelf areas.
\end{abstract}

KEY WORDS: Paralithodes camtschaticus $\cdot$ Zoea $\cdot$ Pagurus $\cdot$ Hyas $\cdot$ Munida $\cdot$ Barents Sea Biogeography $\cdot$ Invasive species

\section{INTRODUCTION}

As is the case of many benthic invertebrates, brachyuran and anomuran decapods have a complex life cycle. During their early life, they pass through several embryological, larval and juvenile stages before maturing to adults (Anger 2006). A majority of marine benthic brachyurans and anomurans brood their fertilized eggs under their abdominal flap and release pelagic zoeae (larvae) which, in high-latitude regions, spend several months in the water column before settling to the seafloor as juveniles. This early part of the life cycle is vulnerable to predation, starvation, unfavorable temperatures and salinities, and

${ }^{*}$ Corresponding author: helena.k.michelsen@gmail.com pollutants leading to a high mortality rate among larvae (Morgan 1995). Moreover, the ability of the surviving larvae to settle in favorable areas is an important factor that can determine the recruitment success of a year class (Anger 2006). Therefore, knowledge on timing, duration and spatial distributions of larvae is crucial for understanding current and potential future population dynamics.

The commercially important red king crab Paralithodes camtschaticus (RKC) has, over the past decades, invaded the northernmost coast of Norway after its intentional introduction to coastal waters near Murmansk, Russia in the 1960s (Orlov \& Ivanov 1978). RKC is one of the largest crabs in the world

(C) The authors 2020. Open Access under Creative Commons by Attribution Licence. Use, distribution and reproduction are unrestricted. Authors and original publication must be credited. 
and is omnivorous, feeding on a wide range of benthic infauna, epifauna and algae (Falk-Petersen et al. 2011). These characteristics make the RKC able to impact the composition, biomass and abundance of the native benthic community in the southern Barents Sea (Pavlova 2008, Falk-Petersen et al. 2011, Fuhrmann et al. 2015, Pedersen et al. 2018). Since 2008, there has been a dual management effort for RKC in Norwegian waters: maintaining a harvestable population within a quota restricted area (east of $26^{\circ} \mathrm{E}$ and to the Russian border) and preventing a southward spread west of this area (west of $26^{\circ} \mathrm{E}$ ) (FKD 2007). The population has nevertheless moved beyond the quota restricted area and is found as far west as the Tromsø Bank (19 E) (Sundet 2014). In Norway, a majority of research on RKC has focused on adults including studies on growth (Windsland et al. 2013), migration patterns (Sundet \& Hjelset 2010, Windsland et al. 2014), mortality (Windsland 2015), feeding habits (Jørgensen \& Primicerio 2007, Fuhrmann et al. 2015, 2017), and size and fecundity of females (Hjelset et al. 2009, 2012, Hjelset 2014). What is known about larval release and the larval part of their life cycle is largely based on field studies (Haynes 1974, Armstrong et al. 1981, Shirley \& Shirley 1988, 1989, Shirley et al. 1990) and laboratory experiments (Paul et al. 1979, 1990, Stevens \& Swiney 2007) conducted in their native area of the northPacific Ocean and Bering Sea. The only work done on the RKC zoeal phase in Norwegian waters is modelling, focusing on potential spread with surface currents and possible settlement localities along the coast (Pedersen et al. 2006). Thus, many aspects of the temporal and spatial dynamics of the RKC zoeal phase remain unknown, leading to uncertainties as to how well larval release is adapted to the new environment, the role this life phase can have as a bottleneck for recruitment, and its potential trophic role in the pelagic habitat (Anger 2006).

There is concern that the RKC in the Barents Sea may compete with native anomurans and brachyurans. Indeed, a recent diet study on RKC using stable isotopes showed that the isotopic niche of juveniles and adults does overlap with that of native brachyurans and anomurans (Fuhrmann et al. 2017). These include Lithodes maja (Linnaeus, 1758), Hyas araneus (Linnaeus, 1758), H. coarctatus Leach, 1815, Pagurus pubescens Krøyer, 1838, P. bernhardus (Linnaeus, 1758), Munida rugosa (Fabricius, 1775), M. sarsi Huus, 1935, Galathea nexa (Embleton, 1836) and G. strigosa (Linnaeus, 1761) (Sokolov 2006). Currently, studies on the timing, duration and spatial overlap of zoeae belonging to these native anomurans and brachyurans and the invasive RKC are rare in the southern Barents Sea (Dvoretskii 2011) and non-existent in north Norwegian waters.

At high latitudes, brachyurans and anomurans release their zoeae in spring and summer (Stübner et al. 2016, Michelsen et al. 2017b), but the exact timing can vary by weeks to months depending on the year, region, and the age and size composition of spawning cohorts. This is attributed to the biogeographical range and life history traits of a given species, and most importantly the environmental variables photoperiod, temperature, salinity, and food availability. Once released, a majority of brachyuran and anomuran zoeae are highly dependent on exogenous food sources and need to encounter food within the first 2 to $6 \mathrm{~d}$ in the water column (Harms \& Seeger 1989, Stevens 2014). These larvae are omnivorous, feeding on co-occurring mesozooplankton like copepod nauplii, other benthic invertebrate larvae, and conspecific and unrelated zoeae (Harms \& Seeger 1989). Phytoplankton is also an important dietary component, particularly when brachyuran and anomuran larvae first enter the water column, and it can sustain survival and growth for extended periods of time (Harms \& Seeger 1989). Presence of food in the water column is therefore crucial for survival of brachyuran and anomuran larvae and larval release should thus be timed with the phytoplankton bloom and presence of zooplankton prey. Zoeae may pass through several molting stages while in the water column, becoming larger and adding new body appendages with each molt. The length of time zoeae spend in the water column depends on species, number of zoeal stages when these are variable within species, and environmental variables that influence growth and development rate. Knowledge on the timing, duration and spatial patterns of zoeae in the water column is important for understanding how they match up with optimal environmental variables and food availability, and thereby the recruitment dynamics of the population.

The present study describes, for the first time, the temporal and spatial patterns of invasive RKC and co-existing native brachyuran and anomuran zoeae within a north Norwegian fjord. To help elucidate the dynamics of egg hatching by RKC in Norwegian waters, the reproductive state of females was determined. We discuss how the temporal and spatial patterns in brachyuran and anomuran zoeae correspond with environmental variables and whether the invasion of the RKC might be enhanced by its reproductive strategies. 


\section{MATERIALS AND METHODS}

\subsection{Study site}

Porsangerfjord is one of the largest fjords in Norway and is located on the northernmost coast $\left(70.0^{\circ}-71.0^{\circ} \mathrm{N}, 25^{\circ}-26.5^{\circ} \mathrm{E}\right)$, adjacent to the Barents Sea (Fig. 1). This fjord is at the westernmost limit of the quota-regulated area for RKC (Fig. 1) and was invaded by RKC starting in 2002 (Sundet 2014). Porsangerfjord has a width of $15-20 \mathrm{~km}$, a length of $100 \mathrm{~km}$ and a mean depth of $200 \mathrm{~m}$. Based on bathymetry and water exchange, the fjord can be separated into 3 basins: outer, middle and inner (Svendsen 1991, Myksvoll et al. 2012, Mankettikkara 2013) (Fig. 1). A shallow $60 \mathrm{~m}$ sill delineates the inner basin; the middle basin is separated from the outer basin by a deep sill at $180 \mathrm{~m}$, while the outer basin is open to the sea (Myksvoll et al. 2012) (see Fig. 1 for location of sills). The outer and middle basins; are classified as semi-enclosed with frequent influx of water from the Norwegian Coastal Current and Atlantic Ocean (Svendsen 1995, Wassmann et al. 1996, Eilertsen and Skarðhamar 2006). The inner basin has little water exchange with the middle basin and experiences some freshwater runoff during spring and summer. It is also characterized as Arctic in nature, due to ice-coverage during winter and spring, temperatures reaching as low as $-1.7^{\circ} \mathrm{C}$ and the presence of a unique Arctic benthic community (Wassmann et al. 1996, Sunnset 2008).

\subsection{Collecting brachyuran and anomuran zoeae and RKC females}

To record temporal patterns of zoeae in the water column, zooplankton samples were collected monthly or every 2 mo between February 2013 and August 2014 from RV 'Johan Ruud' (Table 1). These zooplankton samples were collected at 5 stations along the fjord (Stns 1c, 2c, 3d, 4a, 4b) and in a shallow protected bay (Stn B4) within the middle basin (triangles in Fig. 1, see also Table 1). Stn B4 was the only station sampled in April 2014. For zoeal spatial patterns, zooplankton samples were collected at 18 stations between 11 and 17 April 2013. Stations were arranged in transects across the fjord: 1 transect located in the outer basin (Stns 1a-c), 3 transects in the middle basin (Stns 2a-c, 3a-d and 4a,b), 2 stations in the inner basin (Stns $5 a, b)$, and 4 stations in bays (B1-B4) along the western side of the middle basin (circles in Fig. 1, Table 1). All stations were sampled using a $0.57 \mathrm{~m}$ diameter WP2 plankton net (0.255 $\mathrm{m}^{2}$ sampling area) with $180 \mu \mathrm{m}$ mesh size (Hydrobios) and a filtering cod-end jar. The net was towed vertically from approximately 5 to $10 \mathrm{~m}$ above the seafloor to the sea surface at a speed of $0.5 \mathrm{~m} \mathrm{~s}^{-1}$. When sampling in late winter and spring months 3 hauls were taken at each station. During summer when phytoplankton and jellyfish bloomed, the number of hauls was reduced to 2 or 1 due to severe clogging of the net (see Table S1 in the Supplement at www.int-res.com/articles/suppl/b029p001_supp.pdf for details). Samples were fixed with buffered formaldehyde and seawater at $4 \%$ final concentration.

The spatial distribution and reproductive state of RKC females was determined by capturing crabs in April 2013 and April 2014 using baited square traps. At Stns B1-B6, 2 traps were set out overnight at the same depth range in 2013 (Table 1, Fig. 1). Moreover, an additional pair of traps were set at $48 \mathrm{~m}$ at Stn B4 to check for depth differences in female reproductive state over short distances. Based on the reproductive state of females in 2013, we deployed traps only at Stns B3-B6 in 2014. All individual females were measured for carapace length $(\mathrm{mm} \mathrm{CL}$, measuring from the back of the eye notch to the posterior margin of the carapace), and shell condition and egg characteristics were recorded (Table 2). Shell condition was separated into 2 main categories, soft and hard carapace following procedures described by Donaldson \& Byersdorfer (2005). Soft (or pliable) carapaces show no signs of wear on the spines and are inferred to be $<8$ wk old since molting. Clean hard (or brittle) carapaces that only show slight signs of wear are inferred to be 2 to 12 mo old since molting (Donaldson \& Byersdorfer 2005). Egg characteristics were determined following the descriptions given by Dew (2008) and were divided into 2 categories: eggs of uniform color and empty egg cases (Table 2). Because females molt once a year and then extrude a new batch of eggs, we used the presence of eggs under the abdomen to determine whether the female was mature or immature and shell condition to approximate how far ovigerous females had come in their brooding cycle.

\subsection{Hydrography}

CTD data were provided by the University of Tromsø Sea Monitoring Program, which performs regular environmental surveying at fixed stations in Porsangerfjord (Mankettikkara 2013). Stns 1C, 2c, 3d, $4 \mathrm{a}$ and $4 \mathrm{~b}$ are part of this program and a CTD profile 


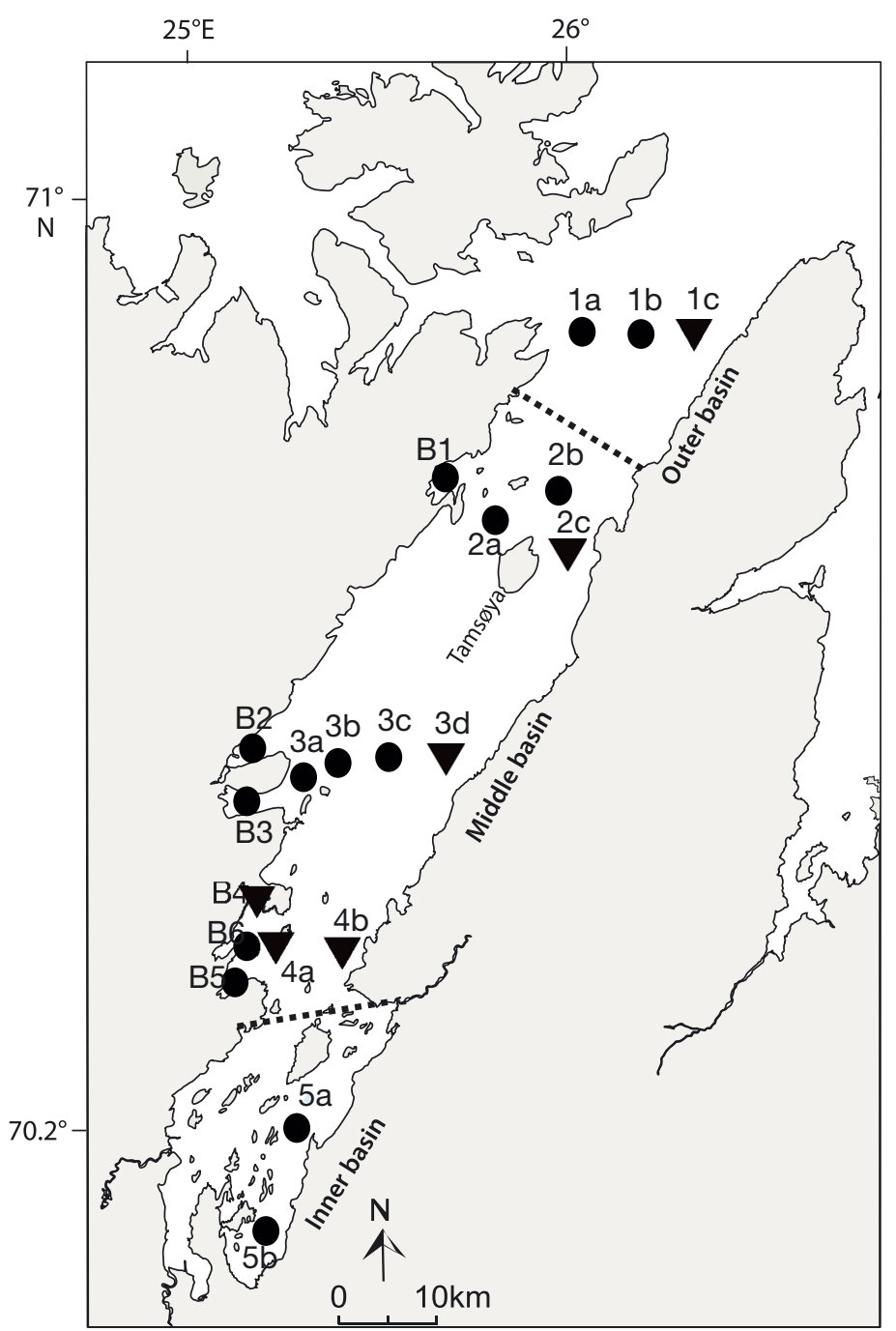

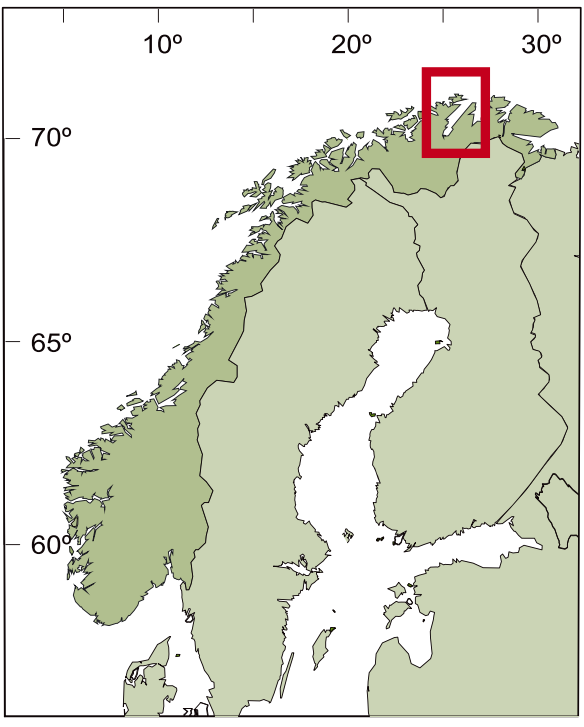

Fig. 1. Porsangerfjord, Norway, showing location of stations sampled between February 2013 and August 2014. Stations sampled for temporal dynamics of decapod larvae are marked with triangles and additional stations sampled for spatial patterns are marked with a circle. Sills that delineate the basins are marked with dotted lines of the water column using a Sea-Bird Electronics SBE9 (Seabird Electronics) was taken at each station prior to zooplankton sampling to record temperature $\left({ }^{\circ} \mathrm{C}\right)$, salinity (PSU) and fluorescence. The CTD station closest to Stn B4 is Stn 4a, at 2.7 nautical miles to the southeast, and was used as a proxy for Stn B4 (Fig. 1, Table 1). To test if there were significant differences in environmental variables between Stns B4 and $4 \mathrm{a}$, a CTD profile was taken at both stations in April 2013 and 2014 (Table 1) and they were compared using a signed rank test. Temperature and fluorescence did not differ significantly between stations, while salinity differed due to lower concentrations in the surface layers (upper $10 \mathrm{~m}$ ) at Stn 4a. In situ fluorescence obtained by the CTD profiles was calibrated to provide an approximate chlorophyll a (chl a) concentration ( $\left.\mu \mathrm{g} \mathrm{l}^{-1}\right)$. Water samples for determination of chl a concentration were collected at Stns B1-B4 in April 2013 and 2014 for calibration of the fluorescence (Fig. 1, Table 1). Water was collected at $0,10,20,30,40$ and $60 \mathrm{~m}$ and was processed following the procedures described in Michelsen et al. (2017b).

\subsection{Laboratory and classification techniques}

In the laboratory, zooplankton samples were diluted to a volume of 200 to $1000 \mathrm{ml}$. Samples with a high concentration of organisms were split in $1 / 2$ to 1/8 using a Folsom-splitter prior to dilution. The sample was sorted through as a whole and all brachyuran and anomuran zoeae were removed by hand. Zoeae were identified to species or genus level and counted, before allocating each individual to a zoeal stage, using a stereomicroscope (Leica MZ16) equipped with a calibrated micrometer. Zoeae were identified and determined to zoeal stage using a variety of taxonomic references (McDonald et al. 1957, Williamson 1957, Pike and Williamson 1958, 
Table 1. Information about all sampling stations, dates sampled, latitude and longitude, depth and equipment used at each station in Porsangerfjord between February 2013 and August 2014

\begin{tabular}{|llcccl|}
\hline Stn & Dates sampled (d/mo/yr) & Latitude (N) & Longitude $(\mathrm{E})$ & Depth $(\mathrm{m})$ & Equipment \\
\hline 1a & 11.4 .13 & $70^{\circ} 52.4^{\prime}$ & $26^{\circ} 01.1^{\prime}$ & 208 & WP2, CTD \\
1b & 11.4 .13 & $70^{\circ} 52.5^{\prime}$ & $26^{\circ} 08.6^{\prime}$ & 240 & WP2, CTD \\
1c & $19.2 .13,20.3 .13,11.4 .13$, & $70^{\circ} 52.5^{\prime}$ & $26^{\circ} 17.0^{\prime}$ & 220 & WP2, CTD \\
& $4.6 .13,22.8 .13,22.10 .13$, & & & & \\
& $14.1 .14,21.5 .14,24.6 .14$, & & & & \\
2a & 11.8 .14 & & & & \\
2b & 11.4 .13 & $70^{\circ} 43.1^{\prime}$ & $25^{\circ} 44.6^{\prime}$ & 216 & WP2, CTD \\
2c & See 1c & $70^{\circ} 45.1^{\prime}$ & $25^{\circ} 57.4^{\prime}$ & 289 & WP2, CTD \\
3a & 12.4 .13 & $70^{\circ} 42.8^{\prime}$ & $25^{\circ} 58.7^{\prime}$ & 262 & WP2, CTD \\
3b & 12.4 .13 & $70^{\circ} 29.5^{\prime}$ & $25^{\circ} 25.2^{\prime}$ & 204 & WP2, CTD \\
3c & 12.4 .13 & $70^{\circ} 33.7^{\prime}$ & $25^{\circ} 42.7^{\prime}$ & 200 & WP2, CTD \\
3d & See 1c & $70^{\circ} 30.6^{\prime}$ & $25^{\circ} 35.0^{\prime}$ & 201 & WP2, CTD \\
4a & See 1c & $70^{\circ} 30.7^{\prime}$ & $25^{\circ} 35.1^{\prime}$ & 202 & WP2, CTD \\
4b & See 1c & $70^{\circ} 21.0^{\prime}$ & $25^{\circ} 14.9^{\prime}$ & 177 & WP2, CTD \\
5a & 15.4 .13 & $70^{\circ} 21.0^{\prime}$ & $25^{\circ} 22.0^{\prime}$ & 140 & WP2, CTD \\
5b & $15.4 .13,24.4 .14$ & $70^{\circ} 12.0^{\prime}$ & $25^{\circ} 16.0^{\prime}$ & 115 & WP2, CTD \\
B1 & 17.4 .13 & $70^{\circ} 07.2^{\prime}$ & $25^{\circ} 11.1^{\prime}$ & 111 & WP2, CTD, crab traps \\
B2 & 15.4 .13 & $70^{\circ} 46.1^{\prime}$ & $25^{\circ} 40.2^{\prime}$ & 126 & WP2, CTD, water samples for Chl $a$, crab traps \\
B3 & 13.4 .13 & $70^{\circ} 31.7^{\prime}$ & $25^{\circ} 09.8^{\prime}$ & 61 & WP2, CTD, water samples for Chl $a$, crab traps \\
B4 & See 1c, 25.4.14 & $70^{\circ} 29.1^{\prime}$ & $25^{\circ} 08.2^{\prime}$ & 73 & WP2, CTD, water samples for Chl $a$, crab traps \\
B5 & $13.4 .13,25.4 .14$ & $70^{\circ} 22.9^{\prime}$ & $25^{\circ} 08.3^{\prime}$ & 72 & WP2, CTD, water samples for Chl $a$, crab traps \\
B6 & $13.4 .13,25.4 .14$ & $70^{\circ} 20.5^{\prime}$ & $25^{\circ} 05.8^{\prime}$ & 61 & Crab traps \\
& & $70^{\circ} 21.3^{\prime}$ & $25^{\circ} 11.1^{\prime}$ & 145 & Crab traps \\
\hline
\end{tabular}

Table 2. Reproductive state of red king crab females (Paralithodes camtschaticus) in April 2013 and 2014. Describing egg characteristics and shell condition used for determination of reproductive state and their interpretation

\begin{tabular}{|c|c|c|c|}
\hline Reproductive state & Egg characteristics & $\begin{array}{l}\text { Shell condition } \\
\text { (time since molt) }\end{array}$ & Interpretation \\
\hline Immature & No eggs & $\begin{array}{l}\text { Soft or pliable carapace } \\
\text { (2-8 wk) }\end{array}$ & Immature crab \\
\hline Ovigerous / soft shell & Eggs of uniform color & $\begin{array}{l}\text { Soft or pliable carapace } \\
(2-8 \mathrm{wk})\end{array}$ & $\begin{array}{l}\text { Ovigerous female with new egg } \\
\text { clutch }\end{array}$ \\
\hline Ovigerous / hard shell & Eggs of uniform color & $\begin{array}{l}\text { Hard or brittle carapace } \\
\text { with some wear (2-12 mo) }\end{array}$ & $\begin{array}{l}\text { Ovigerous female in a pre-hatch } \\
\text { stage }\end{array}$ \\
\hline Hatching & $\begin{array}{l}\text { Mixture of uniformly colored } \\
\text { eggs and empty egg cases }\end{array}$ & $\begin{array}{l}\text { Hard or brittle carapace } \\
\text { with some wear }(2-12 \text { mo) }\end{array}$ & $\begin{array}{l}\text { In the process of hatching } \\
\text { eggs }\end{array}$ \\
\hline Spent & Empty egg cases & $\begin{array}{l}\text { Hard or brittle carapace } \\
\text { with some wear }(2-12 \mathrm{mo})\end{array}$ & $\begin{array}{l}\text { Finished hatching and } \\
\text { ready to molt and spawn }\end{array}$ \\
\hline
\end{tabular}

Roff et al. 1984, Davidson \& Chin 1991, Pohle 1991, Epelbaum et al. 2006). Zoeae that were not identifiable to species level due to damaged or broken appendages were identified only to genus level. Zoeal stages are denoted as zoeal stages I to IV. We also captured a few megalopae or glaucothoe, which are the last larval stage of brachyurans and anomurans, respectively, that settle on the bottom. Anomurans (RKC, Pagurus spp. and Munida spp.) pass through 4 zoeal stages and a final glaucothoe stage (Nakanishi 1987), while Hyas spp. pass through 2 zoeal stages and a final megalopal stage
(Roff et al. 1984). Counts were standardized to number of individuals per square meter (ind. $\mathrm{m}^{-2}$ ), assuming $100 \%$ filtering efficiency of the net and using the sampled depth (Table 1).

\section{RESULTS}

\subsection{Hydrography}

The environmental variables varied both temporally and spatially within the fjord (Fig. 2, Table 3). 
Temperature in the surface decreased to a minimum of $-0.1^{\circ} \mathrm{C}$ in March 2013 (Stn 4b in Fig. 2a). With the exception of Stn 1C, temperatures were generally 1 to 1.5 ${ }^{\circ} \mathrm{C}$ higher in April 2014 compared to April 2013. Surface temperature increased in late spring and summer, reaching a maximum of 9 to $12^{\circ} \mathrm{C}$ in August of both years. The highest bottom temperatures of 6.1 to $7.5^{\circ} \mathrm{C}$ were recorded in October 2013. Surface salinity was between 34 and 35 during winter and spring, but decreased to a minimum of 31 in June 2013 (Fig. 2c). Chl a increased slightly in March and April 2013 (from 0.06 in February to $0.32 \mu \mathrm{g}^{-1}$ in March) suggesting a bloom initiation. In 2014, the bloom started prior to the April sampling and peaked in May at a concentration $6.7 \mu \mathrm{g}^{-1}$. In 2013, we likely missed the peak bloom because of a lack of sampling in May. That year the highest chl a concentrations were measured in August, reaching $1.8 \mu \mathrm{g} \mathrm{l}^{-1}$.

In April 2013, the outer basin was warmer and more saline at both the surface $\left(3.4^{\circ} \mathrm{C}\right.$ and 34.9 , respectively) and the bottom $\left(5.2^{\circ} \mathrm{C}\right.$ and 34.9 , respectively) compared to the other basins (Table 3, and see Michelsen et al. 2017a for spatial contour maps of environmental variables in April 2013). However, chl a concentration was generally low in this basin: reaching $0.2 \mu \mathrm{g} \mathrm{l}^{-1}$ at the surface and a maximum of $0.4 \mathrm{\mu g}^{-1}$ at $20 \mathrm{~m}$ depth (Table 3 ). The middle basin including the bays displayed a slight along-fjord gradient. Bottom temperature and salinity decreased from $2^{\circ} \mathrm{C}$ and 34.2 along the transect of Stns 2a and 2c to $1^{\circ} \mathrm{C}$ and 34.1 along the transect of Stns $4 \mathrm{a}$ and $4 \mathrm{~b}$. Chl a concentration in the middle basin displayed a cross-fjord gradient, with the highest concentrations recorded in the bays and the western side of the fjord. The highest concentrations of chl $a$ were recorded at Stn B3 with a maximum of $2.2 \mu \mathrm{g}^{-1}$ at $30 \mathrm{~m}$ depth (Table 3). The inner basin was the coldest and least saline, with temperatures of 0 to $-1^{\circ} \mathrm{C}$ and a salinity as low as 33.8 (Table 3). Chl a concentrations were similar to those in the outer basin: $0.2 \mu g \mathrm{l}^{-1}$ at the surface and a maximum concentration of $0.4 \mu \mathrm{g} \mathrm{l^{-1 }}$ at $25 \mathrm{~m}$ depth.

\subsection{Composition of brachyuran and anomuran zoeae, glaucothoe and megalopae}

Anomuran and brachyuran zoeae were distinguished into 8 different taxa. Five groups of zoeal stages were identified to species level: RKC, Pagurus pubescens, P. bernhardus, Hyas araneus and $H$. coarctatus. Because some larvae had damage to appendages that are vital for determining the zoea to species level, Pagurus spp. constitutes a mixture of $P$. bernhardus and $P$. pubescens, while Hyas spp. is a mixture of $H$. araneus and $H$. coarctatus (Figs. 3 \& 4). Finally, zoeae belonging to Munida sp. were distinguished but not determined to specific stages.

\subsection{Timing of brachyuran and anomuran zoeae and glaucothoe/megalopae}

Of the brachyuran and anomuran species, $H$. araneus, P. pubescens and RKC zoeae were the most abundant through the whole study period. Brachyuran and anomuran zoeae were uncommon in the outer basin (Stn 1c) and were only caught on 3 sampling dates through the whole field campaign (May 2014 and June 2013, 2014); therefore, the results from this station are presented in Table S2 in the Supplement. For RKC, the earliest stage I zoea was observed in January 2014 (Stn 2c in Fig. 3). This zoeal stage was the most common of all larval stages in 2013, being present from February to April (Fig. 3). That year the abundance of stage I zoeae peaked in March at a majority of stations (up to 57 ind. $\mathrm{m}^{-2}$ at Stn 2c), the exception being bay Stn B4 which had a peak in April (111 ind. $\mathrm{m}^{-2}$ ). RKC stage II zoeae overlapped in time with the last of the stage I zoeae, appearing in the water column at a majority of stations in April 2013 (Fig. 3). In 2014, no stage II zoeae were caught likely because of a lack of sampling between January and May. Only 1 specimen of RKC stage III zoea was found in April 2014 at bay Stn B4. Finally, RKC stage IV zoeae were observed in May 2014 and June 2013, while glaucothoe appeared in early June 2013. The highest abundances of RKC zoeae through the whole study period were recorded at bay Stn B4 (Fig. 3).

For $P$. pubescens, stage I zoeae were present between March and June (Fig. 3) and the peak abundance occurred in April 2013 (31 ind. $\mathrm{m}^{-2}$ at Stn 4a). Stage II zoeae appeared in April and May with the highest abundance occurring in May 2014 (96 ind. $\mathrm{m}^{-2}$ at Stn $4 \mathrm{a}$ ). The first seasonal occurrence of stage III zoeae was in May 2014 (Stns 4a and B4 in Fig. 3) and they were found at all stations in June 2013 (up to 73.5 ind. $\left.\mathrm{m}^{-2} \mathrm{~B} 4\right)$. Stage IV zoeae were found at $1 \mathrm{sta}-$ tion in May 2014 and were present at most stations in June 2014. The density of $P$. pubescens zoeae increased along the fjord, with the highest abundances recorded in the bay and the inner part of the middle basin (Stns B4 and 4a in Fig. 3, Table S2). For P. bernhardus, zoeae were found in low densities (maximum of 30 ind. $\mathrm{m}^{-2}$ at $\mathrm{Stn} 4 \mathrm{~b}$ ) and were never caught at Stns 
a

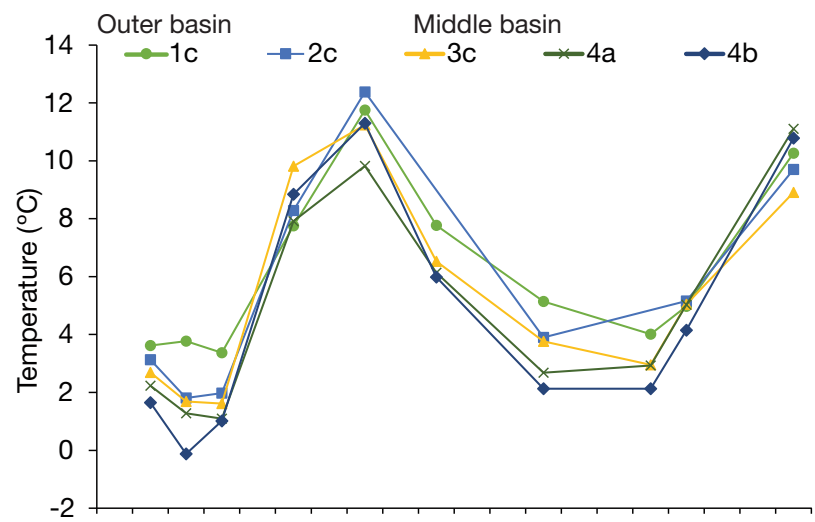

b

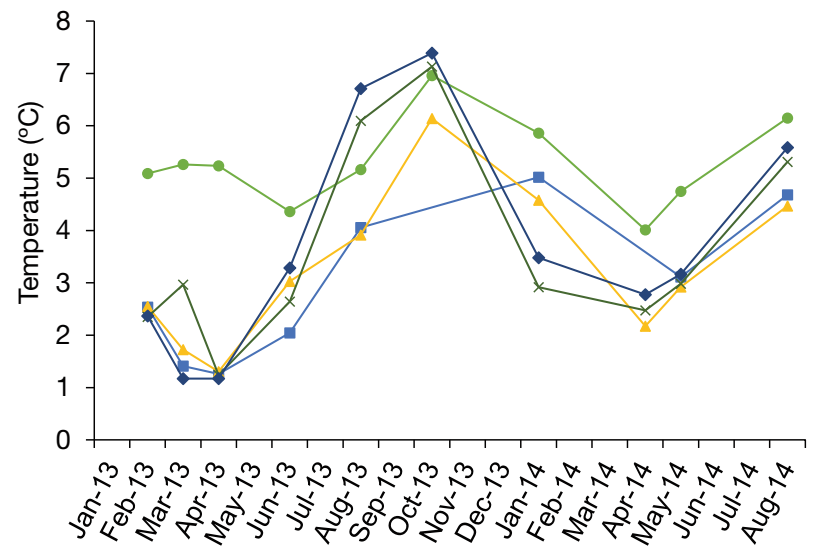

C

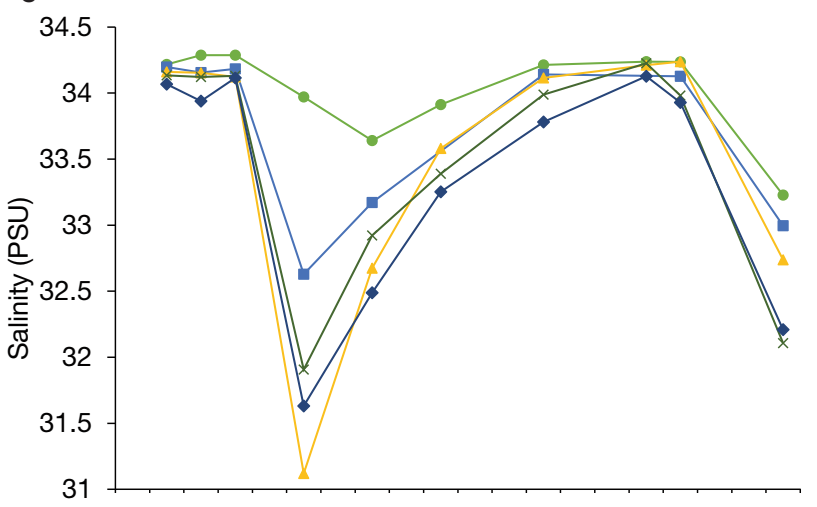

d

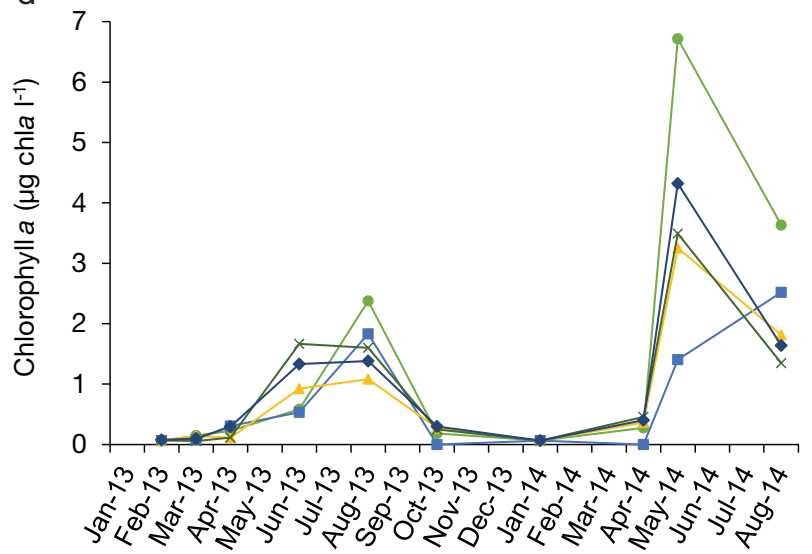

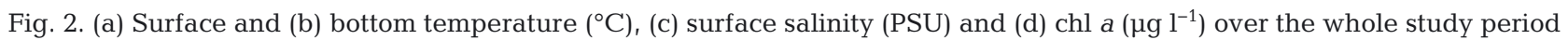
at Stns 1c, 2c, 3c, 4a and 4b in Porsangerfjord, Norway

Table 3. Surface and bottom temperature, surface and bottom salinity (PSU), and surface and maximum chl a $\left(\mu \mathrm{g} \mathrm{l}^{-1}\right)$ at all stations sampled in April 2013 in Porsangerfjord, Norway

\begin{tabular}{|cccccccc|}
\hline \multirow{2}{*}{ Basin } & Stn & $\begin{array}{c}\text { Surface } \\
\text { temp. }\left({ }^{\circ} \mathrm{C}\right)\end{array}$ & $\begin{array}{c}\text { Bottom } \\
\text { temp. }\left({ }^{\circ} \mathrm{C}\right)\end{array}$ & $\begin{array}{c}\text { Surface } \\
\text { salinity }\end{array}$ & $\begin{array}{c}\text { Bottom } \\
\text { salinity }\end{array}$ & $\begin{array}{c}\text { Surface } \\
\text { chl a }\end{array}$ & $\begin{array}{c}\text { Maximum } \\
\text { chl } a \text { (depth m) }\end{array}$ \\
\hline Outer & 1a & 2.9 & 5.2 & 34.3 & 34.9 & 0.19 & $0.29(32)$ \\
& 1b & 2.9 & 5.2 & 34.3 & 34.9 & 0.23 & $0.30(20)$ \\
& 1c & 3.4 & 5.2 & 34.3 & 34.9 & 0.23 & $0.39(20)$ \\
Middle & 2a & 2.3 & 1.6 & 34.2 & 34.2 & 0.45 & $0.46(2)$ \\
& 2b & 3 & 1.8 & 34.3 & 34.2 & 0.37 & $0.41(20)$ \\
& 2c & 2 & 1.3 & 34.2 & 34.1 & 0.31 & $0.32(6)$ \\
& 3a & 1.7 & 0.9 & 34.2 & 34.1 & 0.88 & $1.29(36)$ \\
& 3b & 1.8 & 1.7 & 34.2 & 34.2 & 0.21 & $0.33(19)$ \\
& 3c & 1.5 & 1.3 & 34.2 & 34.1 & 0.12 & $0.28(17)$ \\
& 3d & 1.6 & 1.3 & 34.1 & 34.1 & 0.11 & $0.26(18)$ \\
& $4 \mathrm{a}$ & 1.1 & 1.2 & 34.1 & 34.2 & 0.12 & $0.26(26)$ \\
& 4b & 1 & 1.2 & 34.1 & 34.1 & 0.04 & $0.29(24)$ \\
& $5 \mathrm{a}$ & -1.2 & -0.7 & 33.8 & 33.8 & 0.17 & $0.37(18)$ \\
& 5b & -1.1 & -1.2 & 33.8 & 33.8 & 0.10 & $0.36(22)$ \\
Bays & B1 & 2.5 & 2 & 34.1 & 34.2 & 0.41 & $1.78(30)$ \\
& B2 & 1.8 & 1.4 & 34.1 & 34.2 & 0.32 & $1.15(18)$ \\
& B3 & 0.7 & 0.6 & 34.1 & 34.1 & 0.81 & $2.17(30)$ \\
& B4 & 1 & 0.9 & 34.1 & 34.1 & 0.19 & $0.70(41)$ \\
\hline
\end{tabular}

4a or B4 (Fig. 3). Stage I zoeae appeared only in June. Stage II and III zoeae were observed once in August 2014, while no stage IV zoea was found. Munida sp. did not contribute strongly to the zoeal community in the fjord, but was recorded at a majority of stations in June 2013 and in June and August 2014 at densities ranging from 4 to 76 ind. $\mathrm{m}^{-2}$ (Fig. 3).

Stage I zoeae of $H$. araneus appeared in the water column in March 2013 at Stn 2c. At the other stations, they did not appear until April 2013 (Fig. 4). Stage II zoeae overlapped with stage I zoeae in May 2014 and June 2013. The abundance of zoeae peaked in these months, reaching a maximum of 370 ind. $\mathrm{m}^{-2}$ at $\mathrm{Stn} 4 \mathrm{~b}$ in June 2013. Megalopae were caught at 1 station in June 2013 (4a in Fig. 4). The 2 zoeal stages of $H$. coarctatus 

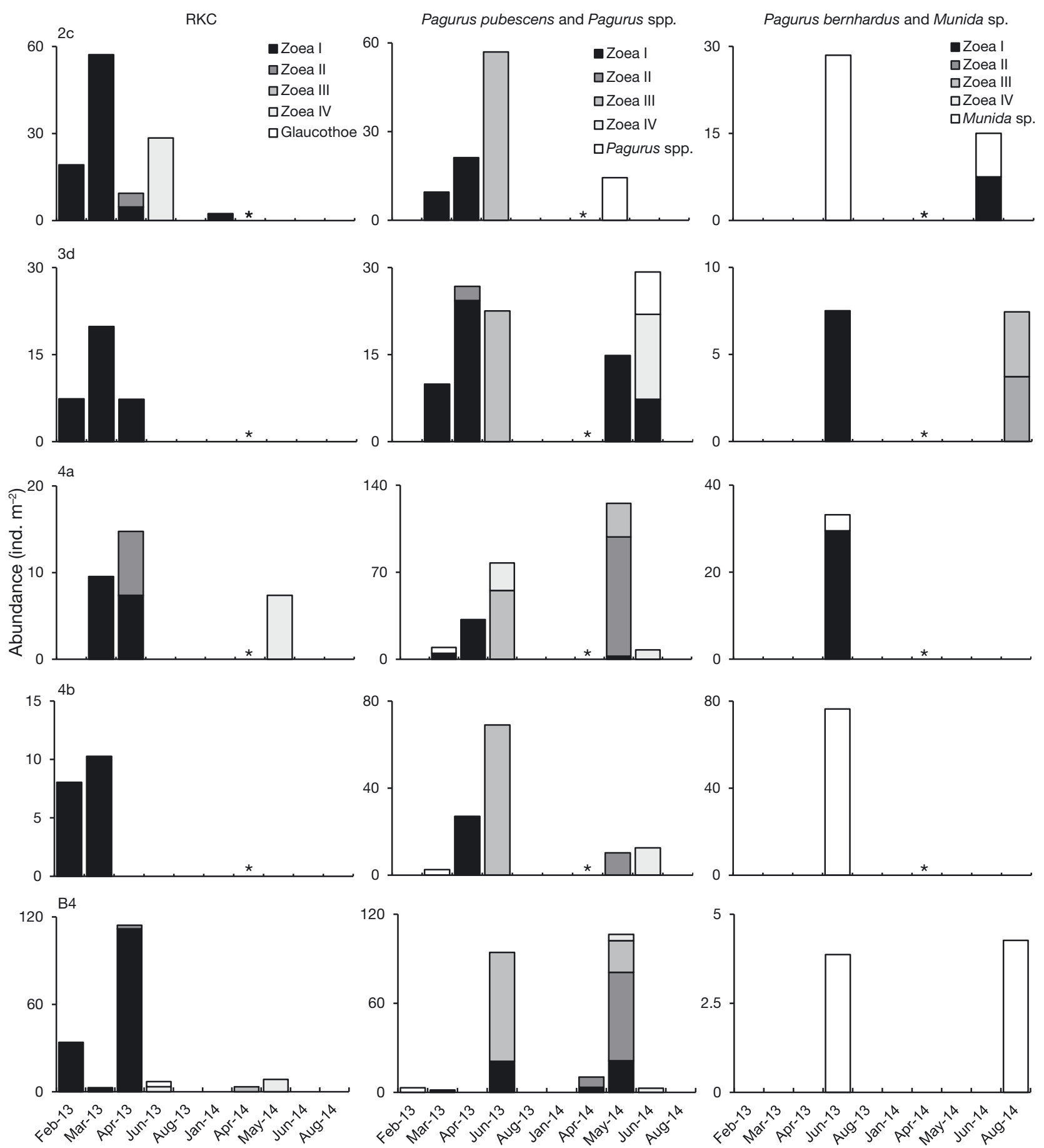

Fig. 3. Seasonal timing and abundance (ind. $\mathrm{m}^{-2}$ ) of zoeal stages of red king crab (RKC, Paralithodes camtschaticus), Pagurus pubescens, P. bernhardus and Munida sp. at Stns 2c, 3d, 4a, 4b and B4 in Porsangerfjord, Norway. Each row of panels represents 1 station. Unsampled dates are marked with an asterisk. Note the different scales on the $y$-axes. See Table S2 in the Supplement for occurrences of zoeae at Stn 1c

were collected in low numbers and no megalopa was found (Fig. 4). The first stage I zoeae were collected in May 2014 and June 2013 at densities of 3 to 104 ind. $\mathrm{m}^{-2}$, while stage II zoeae were only caught at 1 station in June 2014 (Stn 3d in Fig. 4).

\subsection{Spatial patterns of brachyuran and anomuran zoeae in April 2013}

In April 2013, brachyuran and anomuran zoeae were primarily found in the middle basin and bays, 

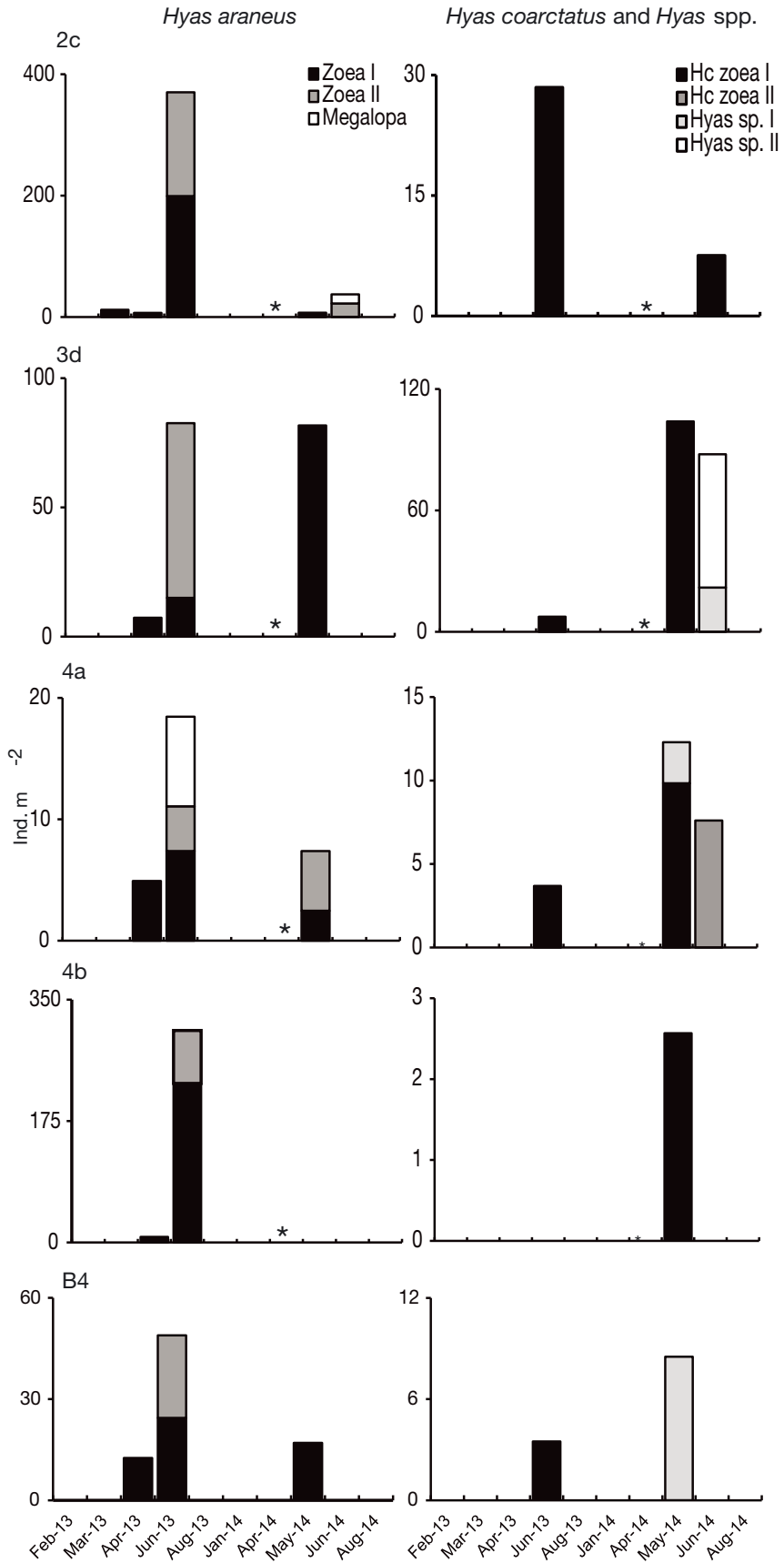

Fig. 4. Seasonal abundance (ind. $\mathrm{m}^{-2}$ ) of zoeal stages of Hyas araneus, H. coarctatus (Hc) and Hyas spp. at Stns 2c, 3d, 4a, 4b and B4 in Porsangerfjord, Norway. Each row of panels represents 1 station. Unsampled dates are marked with an asterisk. Note the different scales on the $y$-axes. See Table $\mathrm{S} 2$ for occurrences of zoeae at Stn 1c

while no zoeae were recorded in the outer basin nor the innermost station in the inner basin (Fig. 5). For $\mathrm{RKC}$, the highest abundances of zoeae were recorded in the bays (23-883 ind. $\mathrm{m}^{-2}$ in Fig. 5a). A mixture of stage I and II RKC zoeae were found througout the fjord, with stage I dominating. RKC stage III zoeae were found at 1 bay station in the outer part of the fjord (Fig. 5a). The genus Pagurus spp. did not show any strong spatial patterns in abundance (Fig. 5b). Pagurus pubescens was more abundant than $P$. bernhardus and represented mostly by its stage I zoea. Hyas araneus was the only larval brachyuran present in April and was found in low abundances throughout the fjord (1-17 ind. $\mathrm{m}^{-2}$ ). Similar to the anomurans, stage I zoeae dominated (Fig. 5c).

\subsection{Reproductive state of female RKC}

There were differences in the reproductive state of RKC females on a relatively small spatial scale (Fig. 6). In April 2013, Stns B1, B2 and B6 differed from the other stations in having mainly immature females along with some generally large, ovigerous females with a hard carapace. In contrast, the larger females at Stns B3, B4 (72 m), B4 (48 m) and B5, were mostly spent or to a lesser degree hatching, while smaller females were mostly either immature or ovigerous with a soft carapace (Fig. 6). In April 2014, the reproductive state of females differed despite sampling the same stations and similar depths as in 2013. This could be because collection occurred approximately 12 to $13 \mathrm{~d}$ later than in 2013 or alternatively the warmer bottom temperatures in 2014 may have led to a faster embryonic development and hence earlier hatching. Relatively more mature females were newly ovigerous in late April 2014 than in mid-April 2013, when most were hatching or spent. In 2014, the larger ovigerous females had a soft carapace while the smaller ovigerous females had a hard carapace. Moreover, only at 1 out of 4 stations (Stn B4) were females in the process of hatching or spent. Overall, the proportion of immature females in samples tended to increase with depth, whereas the proportion of hatching or spent females tended to increase with shoaling.

\section{DISCUSSION}

The present study, being the first to examine the temporal and spatial dynamics of RKC and native brachyuran and anomuran zoeae in the southern Barents Sea, showed that timing, duration and spatial patterns of RKC zoeae in the water column differed from native species. The brachyuran and anomuran zoeae collected in this study belong to native and invasive species residing in the southern Barents Sea (Barnes 
a Paralithodes camtschaticus

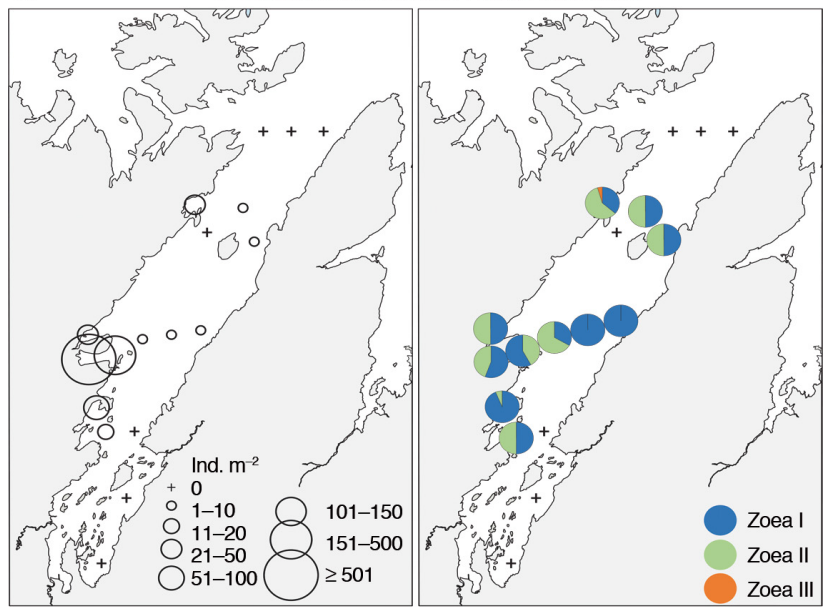

b

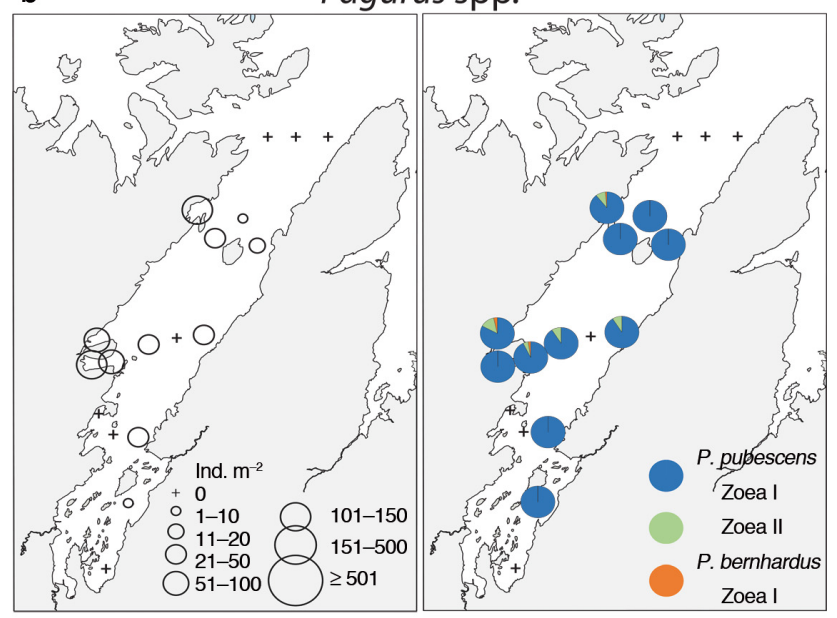

C

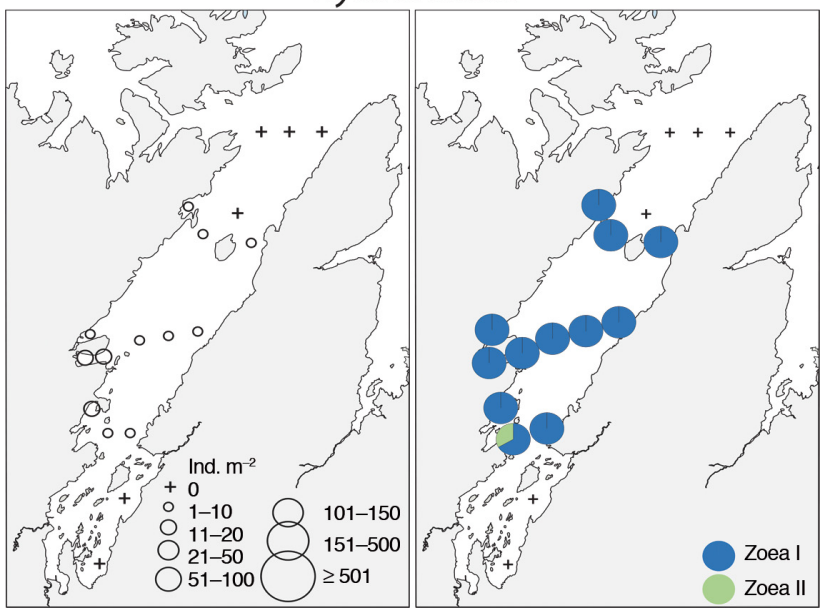

Fig. 5. Spatial patterns in abundance (ind. $\mathrm{m}^{-2}$ ) and stage composition of zoeal stages belonging to (a) Paralithodes camtschaticus, (b) Pagurus pubescens and P. bernhardus and (c) Hyas araneus from 11-17 April 2013 in Porsangerfjord, Norway et al. 2007, Zimina et al. 2015). However, the pelagic larvae of Galathea, which is a common component of the benthic community in Porsangerfjord and the southern Barents Sea (L. L. Jørgensen pers. comm.), were not observed. They may have occurred at other times than those at which we sampled or alternatively they were missed by our spatial sampling grid.

\subsection{Timing and duration of brachyuran and anomuran zoeae in the water column}

For many benthic invertebrates residing at high latitudes, the timing of larval release is triggered by external cues like temperature, light/dark regimes, lunar cycles, tidal cycles, presence of food, or a combination thereof (Thorson 1950). With increased latitude, this can cause a more seasonal appearance of larvae. In this study, zoeae of the brachyuran and anomuran taxa in Porsangerfjord did not appear in the water column simultaneously (Fig. 7). Moreover, zoeal taxa differed in how long they were present in the water column (Fig. 7). RKC zoeae were the first to appear and the present field study is the first to collect zoeae of this species as early as January. This fits well with female spawning migrations in Norwegian waters, which can start as early as December (Sundet \& Hjelset 2010). In native Alaskan waters, the earliest zoeae have been recorded in March in field studies (Shirley \& Shirley 1989), although hatching can start in January in laboratory experiments (Stevens \& Swiney 2007). In the present study, zoeae of the RKC were present in the water column for longer than any of the native anomurans or brachyurans (Fig. 7). Moreover, because a low number of stage IV zoeae and glaucothoe were found in June and none were found in August of both years, it can be assumed that they settled in late June or July. These findings correspond well with studies from their native range (Table 4). We did not sample the late summer and fall months with the same temporal resolution as spring months, thus we cannot estimate for how long zoeae of $P$. bernhardus and Munida sp. were present in the water column. When our results are compared with other studies, there appears to be a latitudinal shift in timing and duration of native brachyuran and anomuran zoeae (Table 4). Zoeae of the boreo-Arctic H. araneus and $P$. pubescens were among the first to appear in Porsangerfjord, and up to 1 mo earlier than in highArctic waters and 2 mo later than in boreal waters (Table 4). The boreal H. coarctatus and P. bernhardus appeared later in spring and summer in this study, and when compared to other studies they emerged 1 

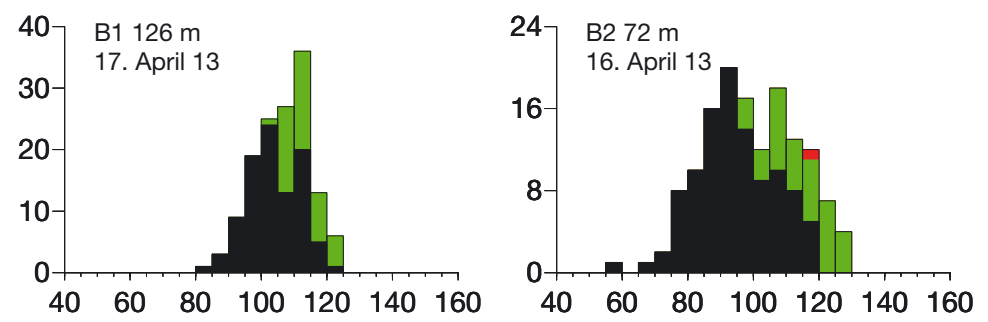

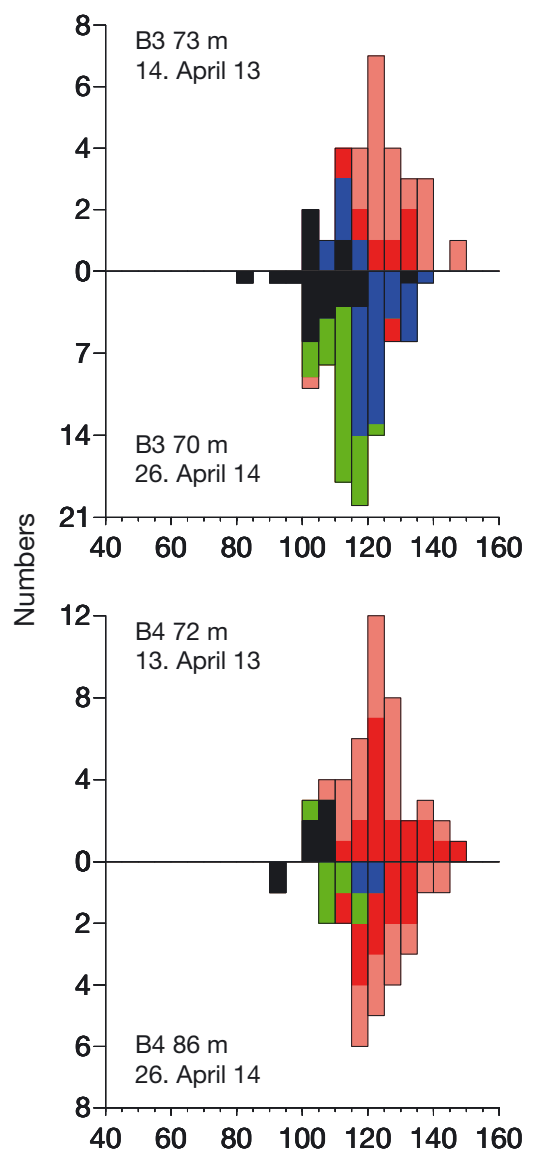

\section{Immature}

Ovigerous - soft shell

Ovigerous - hard shell

Hatching

Spent
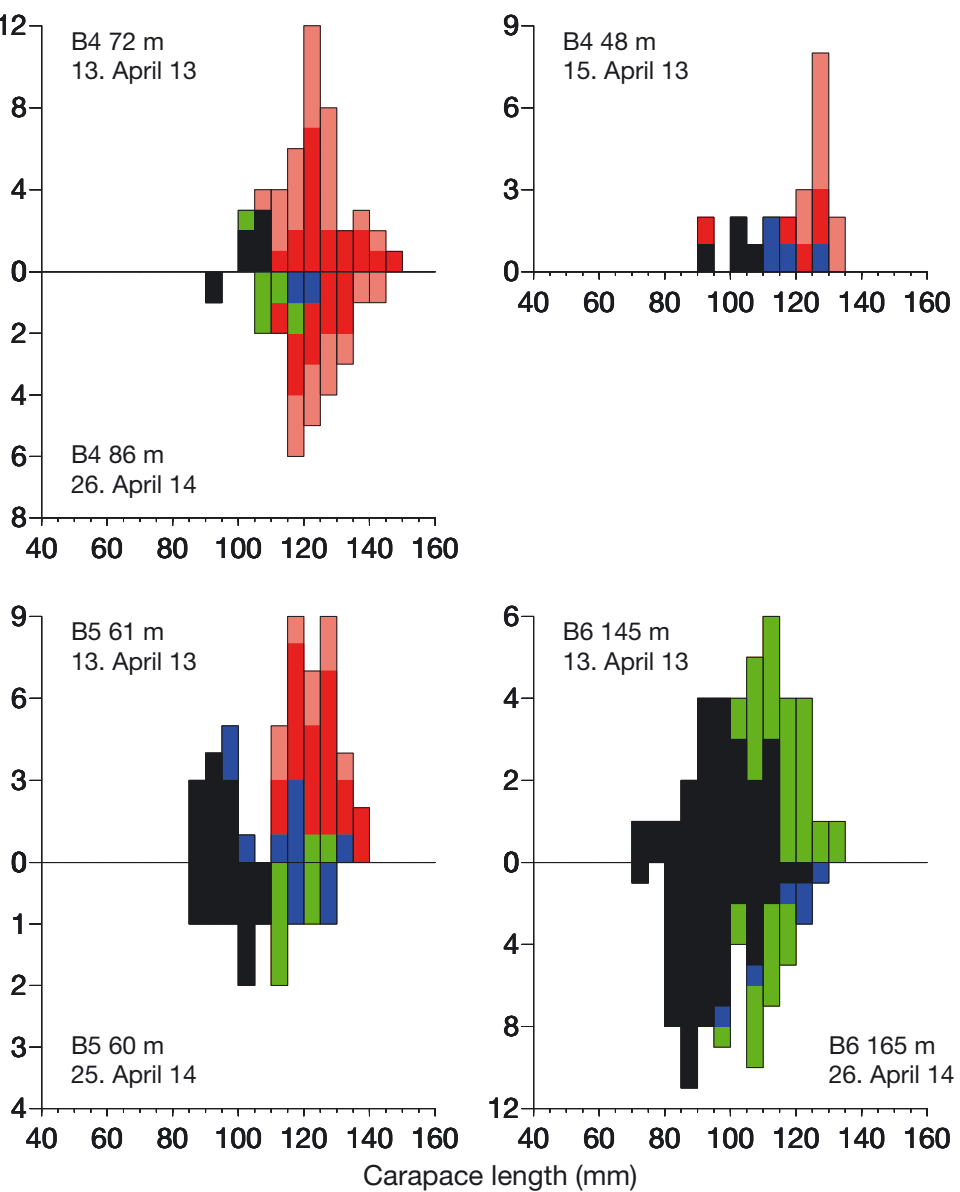

Fig. 6. The reproductive state of red king crab females in April 2013 at bay Stns B1-B6 in Porsangerfjord, Norway. Some bay stations were sampled again in April 2014. Note the different scales on the y-axes mo later than in boreal regions (Table 4). This suggests that there is a latitudinal shift in timing of larval release which could be correlated with the increased environmental seasonality at higher latitudes.

The early and prolonged presence of RKC stage I zoea (January-April) in the plankton is likely due to 2 unique characteristics of the RKC reproductive strategy. First, a study on seasonal migration by RKC adults in Varangerfjord, Norway, found that ovigerous females migrated to shallow waters between December and April and suggested that spawning occurs slightly earlier in Norwegian waters compared to the North Pacific and Bering Sea (Sundet \& Hjelset 2010). Finding stage I zoeae in Porsangerfjord in January and February agrees with these findings and adds to the suggestion that larval release and thus spawning happen earlier in Norwegian waters. Second, unlike a majority of brachyurans and anomurans which hatch their eggs in a matter of hours or days (as summarized by Christy 2011), individual female RKCs have a protracted hatching period lasting $31 \mathrm{~d}$ on average (Stevens \& Swiney 2007). This strategy termed 'diversified bet-hedging' ensures that females will release at least some zoeae at a time that is optimal for survival (i.e. food availability) (Stevens 2014). This is usually an effective reproductive strategy for species residing in highlatitude waters such as the North Pacific and the Barents Sea where the phytoplankton bloom can vary seasonally and interannually. Newly hatched zoeae of RKC need to locate food within $3 \mathrm{~d}$ to survive (Paul \& Paul 1980) and in the present study the first zoeae of RKC appeared in the water column in January and February and thus well in advance of the phytoplankton bloom. This is also a time when the abundance of potential prey (benthic invertebrate larvae and copepod nauplii) is at a minimum in the fjord (Michelsen et al. 2017 b). In the present study, these zoeae may not have found suitable quantities 


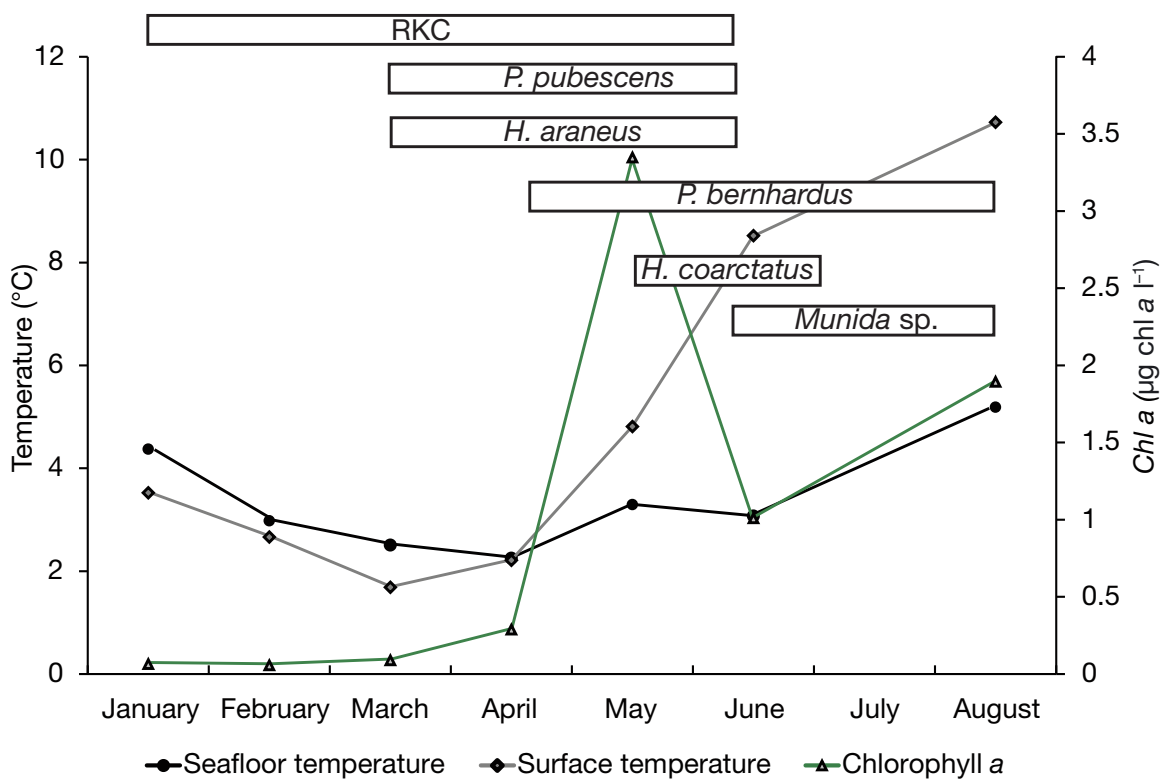

Fig. 7. Timing of brachyuran and anomuran zoeae in the water column and the monthly average seafloor and surface temperature $\left({ }^{\circ} \mathrm{C}\right)$ and chl $a$ $\left(\mu \mathrm{g} \mathrm{l}^{-1}\right)$ in Porsangerfjord from all sampled stations during spring and summer of 2013 and 2014. Timing and environmental averages are based on results shown in Figs. 2-4

of food for survival and growth and thus the dominance of stage I zoeae observed from January to March may be due to recently hatched larvae replacing those that do not survive. Those larvae that are hatched from the end of March are present during the phytoplankton bloom and are thus able to grow and survive, causing a shift toward later zoeal stages in May and June. A combination of protracted hatching (present study), high fecundity (Hjelset et al. 2012) and high adult abundance (J. H. Sundet pers. comm.) are likely strong factors contributing to the successful establishment and persistence of RKC in the southern Barents Sea.

Survival and growth of zoea is influenced by temperature in the water column; thus, hatching can also be timed with optimal temperatures for zoeae. In this study, the boreal $P$. bernhardus and $H$. coarctatus appeared in the water column when temperatures were increasing (Fig. 7). Both species have a narrow physiological optimum temperature of 10 to $12^{\circ} \mathrm{C}$ during their zoeal stages and temperatures below $6^{\circ} \mathrm{C}$ significantly reduce their survival (Dawirs 1979, Anger 1984). Thus for boreal brachyurans and anomurans, larval release in late spring and early summer when surface temperatures are between 5 and $12^{\circ} \mathrm{C}$ likely in- creases survival to settlement in north Norwegian waters. In contrast, the boreo-Arctic $\mathrm{RKC}, H$. araneus and $P$. pubescens zoeae were released while temperatures were decreasing (Fig. 7). Both RKC and $H$. araneus zoeae can tolerate temperatures of -1.8 to

Table 4. The first and last occurrence of brachyuran and anomuran zoeae in the water column in Porsangerfjord, Norway and other geographical areas

\begin{tabular}{|c|c|c|c|}
\hline Species and region & $\begin{array}{l}\text { Latitude } \\
\left({ }^{\circ} \mathrm{N}\right)\end{array}$ & $\begin{array}{l}\text { First and last } \\
\text { occurrence }\end{array}$ & Source \\
\hline \multicolumn{4}{|l|}{ P. camtschaticus } \\
\hline Porsangerfjord, Norway & 71 & January-June & Present study \\
\hline Auke Bay, Alaska & 58.2 & March-June & Shirley \& Shirley (1989) \\
\hline Bering Sea, Alaska & $55-58$ & March-July & Haynes (1974) \\
\hline Bristol Bay, Alaska & $54-58$ & Late April-May & McMurray et al. (1984) \\
\hline \multicolumn{4}{|l|}{ H. araneus } \\
\hline Hornsund, Svalbard & 77 & April-June & Węsławski (1987) \\
\hline Porsangerfjord, Norway & 71 & March-June & Present study \\
\hline Helgoland, Germany & 54 & February-July & Anger \& Nair (1979) \\
\hline \multicolumn{4}{|l|}{ H. coarctatus } \\
\hline Porsangerfjord, Norway & 71 & May-June & Present study \\
\hline West Greenland & 67 & May-August & Stephensen (1913) \\
\hline North Sea & $59-60$ & April-July & Lindley (1987) \\
\hline British Channel & 50 & March-June & Lindley (1987) \\
\hline \multicolumn{4}{|l|}{ P. pubescens } \\
\hline Hornsund, Svalbard & 77 & April-September & Węsławski (1987) \\
\hline Porsangerfjord, Norway & 71 & March-June & Present study \\
\hline \multicolumn{4}{|l|}{ P. bernhardus } \\
\hline Porsangerfjord, Norway & 71 & April-August & Present study \\
\hline North Sea & $59-60$ & Year-round & Lindley (1987) \\
\hline Öresund, Denmark & 56 & March-October & Thorson (1946) \\
\hline British Channel & 50 & February-April & Lindley (1987) \\
\hline
\end{tabular}


$20^{\circ} \mathrm{C}$ (Kurata 1960, Christiansen 1973, Anger 1983, Nakanishi 1987, Shirley \& Shirley 1989). This means that the availability of food and not temperature may be one of the drivers of larval survival of these boreoArctic brachyuran and anomuran species in Norwegian waters.

\subsection{Spatial patterns of RKC zoeae}

Unlike the other brachyurans and anomurans in this study, RKC zoeae were found in higher abundances in bays and along the western side of the fjord in April 2013. These were mainly stage I and II zoeae and their spatial distribution is likely linked to adult spawning migrations and behavior. Adult RKCs perform annual migrations from deep (100-300 m) to shallow sheltered bays $(1-60 \mathrm{~m})$ during winter and early spring to hatch their eggs, molt and spawn (Sundet \& Hjelset 2010). In Porsangerfjord, the western side of the fjord has a coastline with many shallow sheltered bays. The combination of adult spawning migration to shallow areas and topography within Porsangerfjord may result in the concentration of early zoeae along the western coastline. This spatial distribution of early zoeae corresponds well with modeling work done on zoeal RKC advection in Porsangerfjord and other north Norwegian fjords (Pedersen et al. 2006). Importantly, Pedersen et al. (2006) also concluded that a majority of zoeae released in sheltered bays are retained within the fjord and that adult RKCs residing and reproducing within fjords could potentially increase the probability that the glaucothoe stage are able to locate shallow, sheltered and complex benthic habitats which are important for juvenile survival (Loher \& Armstrong 2000). Due to limitations in our study design and very few observations of the later zoeal and glaucothoe stages we are unable to speculate on the spatial settlement patterns of the RKC in Porsangerfjord. Future studies should focus on the spatial patterns of late zoeal and glaucothoe stages in spring to early summer, as indicators of potential settlement areas.

\subsection{Reproductive state of female RKCs}

During the spawning season, RKC females are actively migrating into and out of spawning grounds located in shallow sheltered waters. Whilst at these grounds, they aggregate in localized areas to hatch their eggs, molt and spawn (Dew 2008). It has also been suggested that feeding is reduced during the pre- and postmolt period (Cunningham 1969). Thus, the once-annual, trap-based sampling of females was certainly limited in its ability to fully capture the dynamics of the reproducing population. Sampling various depths captures different parts of the reproducing population but sampling only once each year cannot inform when primiparous females (i.e. carrying and releasing larvae from their first clutch) and multiparous females (i.e. carrying and releasing larvae from their second or subsequent clutch) start releasing their larvae. Moreover, baited traps may not capture females that have reduced their feeding activity. Despite these limitations, some interesting observations were obtained.

In April 2013, the reproductive state of RKCs varied spatially, showing a predominance of immature and ovigerous females with a hard carapace at half the stations, while the other half had mainly hatching or spent females. As the former stations were deep (72-146 m), less sheltered and hardly any females were hatching or spent, it is likely that we sampled outside the spawning/hatching grounds and primarily caught females that had finished spawning in the last 2 to $8 \mathrm{wk}$. The other stations were shallower and likely closer to spawning grounds, thus capturing females in various reproductive states. The high number of females in the process of hatching their eggs in shallow sheltered bays was reflected in the spatial dynamics of RKC zoeae. Finding females in several reproductive states within the fjord suggests that mid- to late-April is a time when RKCs are still in the midst of releasing their larvae and spawning and that larval release can potentially continue into May in Norwegian waters. This corresponds well with reproduction habits in Alaskan waters (Shirley \& Shirley 1988, 1989). In native waters, primiparous females release their larvae 2 to $3 \mathrm{wk}$ in advance of multiparous females (Shirley \& Shirley 1988, Stevens \& Swiney 2007). In the present study, the ovigerous females with a hard carapace might be primiparous and some early spawning multiparous females, which started hatching their eggs in February or March, assuming egg hatching spans approximately $30 \mathrm{~d}$ and postmolt shells harden in 2 to $8 \mathrm{wk}$ in Norwegian waters. This was particularly evident in 2014 at Stn B3 where the small ovigerous females had a hard carapace while the large ovigerous females had a soft carapace. This would agree with finding stage I zoeae in the water column between January and March. Ultimately, the high spatial variability in hatching dynamics shows that spawning dynamics of the RKC are highly variable in Norwegian waters. This warrants a detailed field campaign that looks at 
spawning behavior on a finer spatial grid and also on a temporal scale through their entire spawning/ hatching period (December-June).

\section{CONCLUSIONS}

Brachyuran and anomuran zoeal taxa in Porsangerfjord were released into the water column at different times over a period of 6 mo (January-June) depending on species. Moreover, the zoeal abundance varied depending on species. Brachyurans and anomurans with a broad distribution in boreal to arctic waters (RKC, $P$. pubescens and $H$. araneus) appeared earlier in the water column, were present for a longer time and were more abundant compared to their boreal counterparts ( $P$. bernhardus and $H$. coarctatus). This is likely caused by the former's tolerance to colder temperatures and more variable environments. Several reproductive strategies displayed by the RKC, such as a protracted hatching period, a wide tolerance to temperature during the zoeal phase, and the release of zoeae in shallow protected areas which are plentiful along the complex coastline of northern Norway and Russia, may explain their successful establishment in the southern Barents Sea. This could thus favour the dispersal of RKC further south along the Norwegian coast and potentially north into Svalbard coastal waters.

Acknowledgements. The authors would like to thank the crew of RV 'Johan Ruud' for all the help provided on the cruises and Emma Kube for help in the field. Furthermore, the authors would like to thank the editor and the 3 reviewers for highly constructive comments that improved the manuscript considerably. This study was funded by the UiT The Arctic University of Norway, Tromsø, Norway. The publication charges for this article have been funded by a grant from the publication fund of UiT The Arctic University of Norway.

\section{LITERATURE CITED}

Anger K (1983) Temperature and the larval development of Hyas araneus L. (Decapoda: Majidae); extrapolation of laboratory data to field conditions. J Exp Mar Biol Ecol 69:203-215

Anger K (1984) Development and growth in larval and juvenile Hyas coarctatus (Decapoda, Majidae) reared in the laboratory. Mar Ecol Prog Ser 19:115-123

Anger K (2006) Contributions of larval biology to crustacean research: a review. Invertebr Reprod Dev 49:175-205

Anger K, Nair KKC (1979) Laboratory experiments on the larval development of Hyas araneus (Decapoda, Majidae). Helgol Wiss Meeresunters 32:36-54

Armstrong DA, Incze LS, Wencker DL, Armstrong JL (1981) Distribution and abundance of decapod crustacean lar- vae in the southeastern Bering Sea with emphasis on commercial species. Outer Cont Shelf Environ Assess Program 53:479-856

* Barnes DKA, Kukliński P, Wlodarska-Kowalczuk M (2007) Richness, abundance and shell use of subarctic and arctic hermit crabs. Mar Biol 152:1133-1142

Christiansen ME (1973) The complete larval developement of Hyas araneus (Linnaeus) and Hyas coarctatus Leach (Decapoda, Brachyura, Majidae) reared in the laboratory. Norw J Zool 21:63-89

Christy JH (2011) Timing of hatching and release of larvae by brachyuran crabs: patterns, adaptive significance and control. Integr Comp Biol 51:62-72

Cunningham DT (1969) A study of the food and feeding relationships of the Alaskan king crab Paralithodes camtschatica. MSc thesis, San Diego State College, San Diego, CA

Davidson KG, Chin EA (1991) A comparison of the taxonomic characteristics and duration of the laboratory reared larvae of snow crabs, Chionoecetes opilio (O. Fabricius) and toad crabs (Hyas sp.) from Atlantic Canada. Can Tech Rep Fish Aquat Sci 1762:1-21

* Dawirs RR (1979) Effects of temperature and salinity on larval development of Pagurus bernhardus (Decapoda, Paguridae). Mar Ecol Prog Ser 1:323-329

* Dew CB (2008) Red king crab mating success, sex ratio, spatial distribution, and abundance estimates as artifacts of survey timing in Bristol Bay, Alaska. N Am J Fish Manag 28:1618-1637

Donaldson WE, Byersdorfer SE (2005) Biological field techniques for Lithodid crabs. Sea Grant College Program. University of Alaska, Fairbanks, AK

NDoretskii VG (2011) Distribution of euphausiid and decapod larvae in the spring plankton of the southern Barents Sea. Biol Bull 38:393-399

* Eilertsen HC, Skarðhamar J (2006) Temperatures of north Norwegian fjords and coastal waters: Variability, significance of local processes and air-sea heat exchange. Estuar Coast Shelf Sci 67:530-538

*Epelbaum AB, Borisov RR, Kovatcheva NP (2006) Early development of the red king crab Paralithodes camtschaticus from the Barents Sea reared under laboratory conditions: Morphology and behaviour. J Mar Biol Assoc UK 86:317-333

Falk-Petersen J, Renaud P, Anisimova N (2011) Establishment and ecosystem effects of the alien invasive red king crab (Paralithodes camtschaticus) in the Barents Sea-a review. ICES J Mar Sci 68:479-488

FKD (Fiskeri- og Kystdepartementet) (2007) Stortingsmelding nr. 40 (2006-2007) Management of the red king crab. Ministry of Fisheries and Coastal Affair s, Oslo

Fuhrmann MM, Pedersen T, Ramasco V, Nilssen EM (2015) Macrobenthic biomass and production in a heterogenic subarctic fjord after invasion by the red king crab. J Sea Res 106:1-13

KFuhrmann MM, Pedersen T, Nilssen EM (2017) Trophic niche of the invasive red king crab Paralithodes camtschaticus in a benthic food web. Mar Ecol Prog Ser 565:113-129

Harms J, Seeger B (1989) Larval development and survival in seven decapod species (Crustacea) in relation to laboratory diet. J Exp Mar Biol Ecol 133:129-139

Haynes EB (1974) Distribution and relative abundance of larvae of the king crab, Paralithodes camtschatica, in the southeastern Bering Sea, 1969-1970. Fish Bull 72: 804-812 
Hjelset AM (2014) Fishery-induced changes in Norwegian red king crab (Paralithodes camtschaticus) reproductive potential. ICES J Mar Sci 71:365-373

Hjelset AM, Sundet JH, Nilssen EM (2009) Size at sexual maturity in the female red king crab (Paralithodes camtschaticus) in a newly settled population in the Barents Sea, Norway. J Northwest Atl Fish Sci 41:173-182

Hjelset AM, Nilssen EM, Sundet JH (2012) Reduced size composition and fecundity related to fishery and invasion history in the introduced red king crab (Paralithodes camtschaticus) in Norwegian waters. Fish Res 121-122: 73-80

Jørgensen LL, Primicerio R (2007) Impact scenario for the invasive red king crab Paralithodes camtschaticus (Tilesius, 1815) (Reptantia, Lithodidae) on Norwegian, native, epibenthic prey. Hydrobiologia 590:47-54

Kurata H (1960) Studies on the larva and post-larva of Paralithodes camtschatica. II. Feeding habits of the zoea. Bull Hokkaido Reg Fish Res Lab 21:1-8

Lindley JA (1987) Continuous plankton records: the geographical distribution and seasonal cycles of decapod crustacean larvae and pelagic post-larvae in the northeastern Atlantic Ocean and the North Sea, 1981-3. J Mar Biol Assoc UK 67:145-167

Loher T, Armstrong DA (2000) Effects of habitat complexity and relative larval supply on the establishment of early benthic phase red king crab (Paralithodes camtschaticus Tilesius, 1815) populations in Auke Bay, Alaska. J Exp Mar Biol Ecol 245:83-109

Mankettikkara R (2013) Hydrophysical characteristics of the northern Norwegian coast and fjords. PhD thesis, University of Tromsø

McDonald JD, Pike RB, Williamson DI (1957) Larvae of the British species of Diogenes, Pagurus, Anapagurus and Lithodes (Crustacea, Decapoda). Proc Zool Soc Lond 128: 209-257

McMurray G, Vogel AH, Fishman PA, Armstrong DA, Jewett SC (1984) Distribution of larval and juvenile red king crabs (Paralithodes camtschatica) in Bristol Bay. Outer Cont Shelf Environ Assess Program 53:267-477

Michelsen HK, Nilssen EN, Pedersen T, Reigstad M, Svensen C (2017a) Spatial patterns of spring meroplankton along environmental gradients in a sub-Arctic fjord. Aquat Biol 26:185-197

Michelsen HK, Svensen C, Reigstad M, Nilssen EM, Pedersen $\mathrm{T}(2017 \mathrm{~b})$ Seasonal dynamics of meroplankton in a high-latitude fjord. J Mar Syst 168:17-30

Morgan S (1995) Life and Death in the plankton: Larval mortality and adaptation. In: McEdward L (ed) Ecology of marine invertebrate larvae. CRC Press, Boca Raton, FL

Myksvoll MS, Sandvik AD, Skarðhamar J, Sundby S (2012) Importance of high resolution wind forcing on eddy activity and particle dispersion in a Norwegian fjord. Estuar Coast Shelf Sci 113:293-304

Nakanishi T (1987) Rearing condition of eggs, larvae and postlarvae of king crab. Bull Japan Sea Reg Fish Lab 37:57-161

Orlov YI, Ivanov BG (1978) On the introduction of the Kamchatka king crab Paralithodes camtschatica (Decapoda: Anomura: Lithodidae) into the Barents Sea. Mar Biol 48: 373-375

Paul AJ, Paul JM (1980) The effect of early starvation on later feeding success of king crab zoeae. J Exp Mar Biol Ecol 44:247-251

Paul AJ, Paul JM, Shoemaker PA, Feder HM (1979) Prey concentrations and feeding response in laboratory-reared stage-one zoeae of king crab, snow crab, and pink shrimp. Trans Am Fish Soc 108:440-443

*Paul AJ, Paul JM, Coyle KO (1990) Growth of stage I king crab larvae of Paralithodes camtschatica (Tilesius) (Decapoda: Lithodidae) in natural communities. J Crustac Biol 10:175-183

* Pavlova LV (2008) Effect of juvenile red king crabs on zoobenthos in Kola Bay (Barents Sea). Dokl Biol Sci 422:312-315

* Pedersen O, Nilssen EM, Jørgensen LL, Slagstad D (2006) Advection of the red king crab larvae on the coast of North Norway-A Lagrangian model study. Fish Res 79: 325-336

* Pedersen T, Fuhrmann MM, Lindstrøm U, Nilssen EM and others (2018) Effects of the invasive red king crab on food web structure and ecosystem properties in an Atlantic fjord. Mar Ecol Prog Ser 596:13-31

Pike RB, Williamson DI (1958) Crustacea Decapoda: larvae. XI. Paguridea, Coenobitidea, Dromiidea, and Homolidea. Cons Int Explor Mer 81:1-9

* Pohle GW (1991) Larval development of Canadian Atlantic oregoniid crabs (Brachyura: Majidae), with emphasis on Hyas coarctatus alutaceus Brandt, 1851, and a comparison with Atlantic and Pacific conspecifics. Can J Zool 69: 2717-2737

Roff JC, Davidson K, Pohle G, Dadswell MJ (1984) A guide to the marine flora and fauna of the Bay of Fundy and Scotian Shelf: larval Decapoda: Brachyura. Can Tech Rep Fish Aquat Sci, Vol 1322. Fisheries and Oceans Canada, St. Andrews

Shirley SM, Shirley TC (1989) Interannual variability in density, timing and survival of Alaskan red king crab Paralithodes camtschatica larvae. Mar Ecol Prog Ser 54:51-59

Shirley TC, Shirley SM (1988) Variables affecting hatching time of Alaskan red king crab. Am Zool 28:63A

Shirley TC, Shirley SM, Korn S (1990) Incubation period, molting and growth of female red king crabs: effects of temperature. Proc Int Symp King and Tanner Crabs. Alaska Sea Grant College program report, Anchorage, AK

Sokolov V (2006) Zoogeography of decapod crustaceans in the Euro-Asiatic Seas of Arctic region. ICES CM 2006/D: 09, Maastricht

Stephensen K (1913) Account of Crustacea and Pycnogonida collected by Nordmann in 1911 in West Greenland. Medd Gronl 51:55-77

Stevens B (2014) Developement and biology of king crab larvae. In: Stevens B (ed) King crabs of the world, biology and fisheries management. CRC Press, Boca Raton, FL, 233-260

Stevens BG, Swiney KM (2007) Hatch timing, incubation period, and reproductive cycle for captive primiparous and multiparous red king crab, Paralithodes camtschaticus. J Crustac Biol 27:37-48

* Stübner EI, Søreide JE, Reigstad M, Marquardt M, Blachowiak-Samolyk K (2016) Year-round meroplankton dynamics in high-Arctic Svalbard. J Plankton Res 38: $522-536$

Sundet JH (2014) The red king crab (Paralithodes camschaticus) in the Barents Sea. In: Fernandez L (ed) Marine invasive species in the Arctic. TemaNord Environment, Copenhagen, p 71-82

Sundet JH, Hjelset AM (2010) Seasonal depth distribution of the red king crab (Paralithodes camtschaticus) in Varangerfjorden, Northern Norway. In: Kruse GH, Eckert GL, Foy RJ, Lipcius RN, Sainte-Marie B, Stram DL, Woodby D (eds) Biology and management of exploited 
crab populations under climate change. Alaska Sea Grant, University of Alaska, Fairbanks, p 90-104

Sunnset BH (2008) Mapping marine life in Porsangerfjorden. Research News, Vol 9. Institute of Marine Research, Bergen

Svendsen H (1991) Preliminary results from a hydrophysical investigation of Porsangerfjord, Altafjord and adjacent coastal waters, June-August 1990. Report of the Geophysical Institute, University of Bergen

Svendsen H (1995) Physical oceanography of coupled fjordcoast systems in northern Norway with special focus on frontal dynamics and tides. In: Skjodal HR, Hopkins C, Erikdstad KE, Leinaas HP (eds) Ecology of fjords and coastal waters. Elsevier, New York, NY, p 149-164

Thorson GAW (1946) Reproduction and larval development of Danish marine bottom invertebrates with special reference to planktonic larvae in the Sound (Øresund). Medd Dan Fisk Havunders, Vol 4. Danish Institute for Fishery and Marine Research, Copenhagen

Thorson G (1950) Reproductive and larval ecology of marine bottom invertebrates. Biol Rev Camb Philos Soc 25:1-45

Wassmann P, Svendsen H, Keck A, Reigstad M (1996) Selected aspects of the physical oceanography and parti-

Editorial responsibility: Bernard Sainte-Marie, Mont-Joli, Quebec, Canada cle fluxes in fjords of northern Norway. J Mar Syst 8: 53-71

Wessławski JM (1987) Occurrence and ecology of Decapoda, Crustacea from South Spitsbergen. Pol Polar Res 8: 121-134

Williamson DI (1957) Crustacea Decapoda: larvae. I. General. Cons Int Explor Mer 67:1-6

*Windsland K (2015) Total and natural mortality of red king crab (Paralithodes camtschaticus) in Norwegian waters: catch-curve analysis and indirect estimation methods. ICES J Mar Sci 72:642-650

* Windsland K, Hvingel C, Nilssen EM, Sundet JH (2013) Evaluation of von Bertalanffy growth curves for the introduced red king crab (Paralithodes camtschaticus) in Norwegian waters. Fish Res 145:15-21

炎Windsland K, Hvingel C, Nilssen EM, Sundet JH (2014) Dispersal of the introduced red king crab (Paralithodes camtschaticus) in Norwegian waters: a tag-recapture study. ICES J Mar Sci 71:1966-1976

Zimina OL, Lyubin PA, Jørgensen LL, Zakharov DV, Lyubina OS (2015) Decapod crustaceans of the Barents Sea and adjacent waters: species composition and peculiarities of distribution. Arthropoda Sel 24:417-428

Submitted: July 30, 2018; Accepted: September 2, 2019

Proofs received from author(s): December 17, 2019 